\title{
THE BODIES ADMINISTERING UNEMPLOYMENT COMPENSATION LAWS
}

\author{
Robert N. Cook*
}

The organization of the governmental bodies charged by the state unemployment compensation acts ${ }^{1}$ with the administration of their respective systems is too recent to permit of extended analysis. In the table which accompanies this article the structure of the principal federal and state administrative bodies is outlined. This table does not embrace the public employment service which is provided in every state nor the additional machinery for the settlement of benefit claims. These administrative agencies and their functions are discussed elsewhere in this symposium. ${ }^{2}$ The powers and duties of the bodies considered herein are set forth in the several statutes in very general terms. The following summary indicates the principal provisions.

I. Rule-Making Power. In every state, the commission is granted power to make rules and regulations. In two states, a distinction is drawn between rules relating to administration, ${ }^{3}$ and those "interpreting or applying" the act." Rules of the latter type may be adopted only after a public hearing before the commission, following published notice or after discussion with the state-wide advisory council, and become effective upon filing with the secretary of state. In three jurisdictions, ${ }^{5}$ there is only the requirement of notice in advance of the effective date of the regulation. The other states ${ }^{6}$ have no express requirement of publication prior to the effective date of the rules, but usually require their publication. In two of these, ${ }^{7}$ regulations are

- A.B., 1933, Bucknell University. Member of the third year class in the Duke University School of Law. Member of the Editorial Board of the Duke Bar Association Journal.

1 Alabama, Laws 1935, Sen. B. No. 395; California, Stat. I935, c. 352; District of Columbia, Public, No. 386, 74th Cong., Ist Sess. (1935); Massachusetts, GeN. Laws, c. I5IA (Laws 1935, c. 479); New Hampshire, Laws I935, c. 99, as amended by c. 142; New York, N. Y. Consol. Laws, art. I 8 c. 31, $\$ \$ 500-531$ (Laws 1935, c. 468); Oregon, Laws 1935, Spec. Sess., H. B. No. 71; Utah, Laws 1935, c. 38; Washington, Laws I935, c. I45; Wisconsin, WIs. Sтат. (I933) c. I08, as amended by Laws I935, c. I92, 272, 446; North Carolina, Laws 1935, c. 492 (enabling act which has not been utilized).

(Subsequent citations of these acts will be by the pertinent section or sections only. The fact that in the succeeding discussion there is no reference to a particular section of a state act does not necessarily mean that the commission of that state does not have the power to which the reference relates since the same power may be exercised under the more general grants.)

${ }^{2}$ See Stead, The Rolle of the Public Employment Service in the Unemployment Compensation Program, infra, p. Ioo; Dodd, Administering Unemployment Compensation Benefit Claims, infra, p. 107.

${ }^{3}$ Ala. §ro (a); Wash. §II (I).

Ala. §Io (b); Wash. §II (2).

${ }^{8}$ Calif. $\$ 90$ (a)-(b) (3o days); Dist. of Col. $\$ 14$ (b) ( 5 days); Wis. $\$ 108.14$ (2) (ro days).

'Mass. $\$ \$ 9$ J-40; N. H. \$\$4I-42; N. Y. \$5I8; Ore. \$\$19 (a), 20 (a); Utah, \$27 (a), Rev. Stat. (1933) 42-I-95.

${ }^{7}$ Mass. $\$ 9 \mathrm{~J}$; N. H. $\$ 4$ r. 


\begin{tabular}{|c|c|c|c|c|}
\hline JURISDICTION* & NAME OF BODY & $\begin{array}{l}\text { NUMBER or } \\
\text { MEMBERS }\end{array}$ & GRoups Represented & $\begin{array}{c}\text { QUALIPICATIONS AND } \\
\text { RESTRICTIONB }\end{array}$ \\
\hline $\begin{array}{l}\text { UNITED STATES } \\
\text { (Social Security Act, } \\
\text { Pub., No. 271, 74th } \\
\text { Cong., Ist Sess., } \\
\text { 1935) } \\
\end{array}$ & $\begin{array}{l}\text { Social Security } \\
\text { Board } \\
\text { [tit. VII, \& 701] }\end{array}$ & 3 [Ibid.] & . & $\begin{array}{l}\text { Must not cngage in any other } \\
\text { business, vocation, or employ- } \\
\text { ment; not more than } 2 \text { mem- } \\
\text { bers of same political party } \\
\text { [Ibid.] }\end{array}$ \\
\hline \multirow[t]{3}{*}{$\begin{array}{l}\text { ALABAXsa } \\
\text { (LaW3 1935, Sen. B. } \\
\text { No. 395) }\end{array}$} & $\begin{array}{l}\text { Unemployment } \\
\text { Compensation } \\
\text { Commission } \\
{[\$ 9(\mathrm{a})]} \\
\end{array}$ & $\begin{array}{l}3[89(a)] \\
\text { Quorum: } 2 \\
{[89(d)]}\end{array}$ & & $\begin{array}{l}\text { Must not be "officer or com- } \\
\text { mittee member of any political } \\
\text { party organization" }[89 \text { (a)] }\end{array}$ \\
\hline & $\begin{array}{l}\text { State-Wide } \\
\text { Advisory } \\
\text { Council }[8 \text { (8) } 10(\mathrm{e})\end{array}$ & $\begin{array}{l}\text { Not less than } 9 \\
{[810(\mathrm{c})]}\end{array}$ & $\begin{array}{l}\text { Equal number represent em- } \\
\text { ployees, employers, public } \\
\text { is } 10 \text { (e)] }\end{array}$ & $\begin{array}{l}\text { Must be fairly representative } \\
\text { of Group }|\& 10(\mathrm{e})|\end{array}$ \\
\hline & $\begin{array}{l}\text { Local Advisory } \\
\text { Councils } \\
{[810(\mathrm{e})]} \\
\end{array}$ & Not specified & $\begin{array}{l}\text { Equal number represent em- } \\
\text { ployees, cmployers, public } \\
{[\$ 10(\mathrm{e})]}\end{array}$ & $\begin{array}{l}\text { Must be fairly representative } \\
\text { of group } \\
\text { I5 } 10(\mathrm{e})]\end{array}$ \\
\hline $\begin{array}{c}\text { Calmpormia } \\
\text { (Stat. 1935, c. 352) }\end{array}$ & $\begin{array}{l}\text { Unemployment } \\
\text { Reserves } \\
\text { Commission } \\
{[\$ 75]}\end{array}$ & 5 [8 78] & 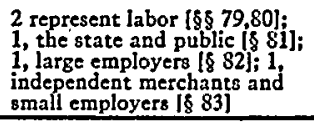 & \\
\hline $\begin{array}{c}\text { District of } \\
\text { Covtumbia } \\
\text { (Pub. No. 386, 74th } \\
\text { Cong., 1st Ses8.,1935) } \\
\end{array}$ & $\begin{array}{l}\text { Distriet Unem- } \\
\text { ployment Com- } \\
\text { pensation Board } \\
\$ 816(a)] \\
\end{array}$ & 5 [8 $16(\mathrm{a})]$ & $\begin{array}{l}3 \text { Comm'rs of District, ex } \\
\text { officio; } 1 \text { representative, em- } \\
\text { ployers: } 1 \text { representative, em- } \\
\text { ployees } 1816 \text { (a)] }\end{array}$ & \\
\hline \multirow[t]{2}{*}{$\begin{array}{l}\text { MASSACHUSETTS } \\
\text { (Laws } 1935, \text { c. 479, } \\
\text { creating GEN. LAWs, } \\
\text { c. 151A) }\end{array}$} & $\begin{array}{l}\text { Unemployment } \\
\text { Compensation } \\
\text { Commission } \\
(\$ 9 I(\mathrm{a})]\end{array}$ & $\begin{array}{l}3[89 \mathrm{I}(\mathrm{a})] \\
\text { Quorum:2 } \\
{[189 \mathrm{I}(\mathrm{c})]}\end{array}$ & $\begin{array}{l}1 \text { represents employers; } 1 \text {, } \\
\text { employees; } 1 \text {, the public } \\
{[\S 9 \mathrm{I}(\mathrm{a})]}\end{array}$ & $\begin{array}{l}\text { Not more than } 2 \text { of same polit- } \\
\text { ical party: must not eerve on } \\
\text { any political party cominittee } \\
\text { must be fairly representative of } \\
\text { group } 189 \mathrm{I} \text { (a)] }\end{array}$ \\
\hline & $\begin{array}{l}\text { State Advisory } \\
\text { Council } \\
{[89 \mathrm{~N}(\mathrm{a})]} \\
\end{array}$ & $9[59 \mathrm{~N}(\mathrm{a})]$ & $\begin{array}{l}3 \text { represent employers; } 3, \text { em- } \\
\text { ployees; } 3 \text {, the public } \\
{[89 \mathrm{~N}(\mathrm{a})]}\end{array}$ & $\begin{array}{l}\text { Not more than } 5 \text { of same party: } \\
\text { must be fairly representative of } \\
\text { group } 189 \mathrm{~N} \text { (a)] }\end{array}$ \\
\hline $\begin{array}{l}\text { NEW HAYPSHIRE } \\
\text { (Laws 1935, c 99) }\end{array}$ & $\begin{array}{l}\text { Commissioner of } \\
\text { Labor }[\S 40]\end{array}$ & 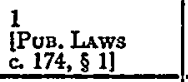 & & \\
\hline \multirow{2}{*}{$\begin{array}{l}\text { NEW York } \\
\text { (Laws 1935, c. } 468, \\
\text { adding Consoz. } \\
\text { LAws, c. 31, art. 18) }\end{array}$} & $\begin{array}{l}\text { Industrial Com- } \\
\text { missioner } \\
1 \leqslant 518 \text { (1)] }\end{array}$ & $\begin{array}{l}1 \text { [Consol. LAws } \\
\text { c. } 32810]\end{array}$ & & \\
\hline & $\begin{array}{l}\text { State Advisory } \\
\text { Council } \\
{[\$ 518(4)]} \\
\end{array}$ & $9[\S 518(4)]$ & $\begin{array}{l}3 \text { represent employers; } 3 \text {, em- } \\
\text { ployees; } 3 \text {, the public } \\
{[8518 \text { (4)] }}\end{array}$ & $\begin{array}{l}\text { Must be fairly representative } \\
\text { of group } \\
|8518(4)|\end{array}$ \\
\hline $\begin{array}{l}\text { OREgoN } \\
\text { (Laws 1935, Spec. } \\
\text { Sess., H. B. No. 71) }\end{array}$ & $\begin{array}{l}\text { Unemployment } \\
\text { Compensation } \\
\text { Commission } \\
{[\$ 18]}\end{array}$ & $\begin{array}{l}31818] \text { [CODE } \\
\text { 49-1802] } \\
\text { Quorum: } 2 \\
\text { [CoDE 49-1805] }\end{array}$ & $\begin{array}{l}\text { Members, Ind. Accident } \\
\text { Comm'n, ex officio, [8 18] } \\
\text { of whom } 1 \text { represents em- } \\
\text { ployers; } 1 \text {, employees; I, the } \\
\text { public [CopE, 49-1802] }\end{array}$ & $\begin{array}{l}\text { Not more than } 2 \text { from one polit- } \\
\text { ical party. [lobid.i] must hold no } \\
\text { other office of profit or in any } \\
\text { political party } \\
{[I d .49 .1803]}\end{array}$ \\
\hline \multirow[t]{2}{*}{$\underset{\text { (Laws 1935, c. 38) }}{\text { UTAz }}$} & $\begin{array}{l}\text { Industrial Com- } \\
\text { mission } \\
{[827(a)]}\end{array}$ & $\begin{array}{l}3 \text { [REv. STAT. } \\
42-1-1] \text { QuOrum: } \\
2[\text { Id. } 42-1-6] \\
\end{array}$ & & $\begin{array}{l}\text { Not more than } 2 \text { from same } \\
\text { political party } \\
{[I d .42-1-1]}\end{array}$ \\
\hline & $\begin{array}{l}\text { Advisory } \\
\text { Council } \\
{[827 \text { (b) }]} \\
\end{array}$ & Not specified & $\begin{array}{l}\text { Equal number represent em- } \\
\text { ployers, employees, and the } \\
\text { public is } 27 \text { (b)] }\end{array}$ & \\
\hline \multirow[t]{3}{*}{$\begin{array}{l}\text { WASAINGTON } \\
\text { (Laws 1935, c. 145) }\end{array}$} & $\begin{array}{l}\text { Unemployment } \\
\text { Compensation } \\
\text { Commission } \\
{[\$ 10(1)]}\end{array}$ & $\begin{array}{l}3[\$ 10(1)] \\
\text { Quorum: } \\
\text { [8 } 10(3)]\end{array}$ & & $\begin{array}{l}\text { Must not engage in any other } \\
\text { business, vocation, or cmploy- } \\
\text { ment, or be officer or committee } \\
\text { member of any political party } \\
{[\$ 10(1)]}\end{array}$ \\
\hline & $\begin{array}{l}\text { Statewide Ad- } \\
\text { visory Council } \\
{[811(5)]} \\
\end{array}$ & Not specified & $\begin{array}{l}\text { Equal number represent em- } \\
\text { ployers, employees, and the } \\
\text { public is } 11(5)]\end{array}$ & \\
\hline & $\begin{array}{l}\text { Local Advisory } \\
\text { Councils } \\
{[\$ 11(5)]} \\
\end{array}$ & Not specified & $\begin{array}{l}\text { Equal number represent em- } \\
\text { ployers, employees, and the } \\
\text { public }[811(5)]\end{array}$ & \\
\hline \multirow{2}{*}{$\begin{array}{l}\text { Wisconsin } \\
\text { (StAт. (1933) c. 108, } \\
\text { as amended by Laws } \\
1935, \text { c. 192, 272, } \\
\text { 446) }\end{array}$} & $\begin{array}{l}\text { Industrial } \\
\text { Commission } \\
{[8108.14 \text { (1)] }}\end{array}$ & $\begin{array}{l}3[8101.02] \\
\text { Quorum: } \\
{[18101.03]} \\
\end{array}$ & & \\
\hline & $\begin{array}{l}\text { Advisory Em- } \\
\text { ployment Com- } \\
\text { mittees (for local } \\
\text { district, indus- } \\
\text { tries, or state) } \\
{[8108.14(5)]} \\
\end{array}$ & $\begin{array}{l}\text { At least } 3 \\
{[\delta 108.14(5)]}\end{array}$ & $\begin{array}{l}\text { One or more representatives } \\
\text { of cmployers, employees, and } \\
\text { public }[\$ 108.14(5)]\end{array}$ & \\
\hline
\end{tabular}

The citations in brackets refer to the unemployment compensation acts cited in the left-hand column except whese reference to statutes in the state codes is specified. 


\begin{tabular}{|c|c|c|c|}
\hline MOde of APPOINTLLENT & Tersy & COMPENSATION & Ressoval \\
\hline $\begin{array}{l}\text { By President, with advice and con- } \\
\text { sent of Senate (Chairman desig- } \\
\text { nated by President) } \\
\text { [Ibid.] }\end{array}$ & $\begin{array}{l}6 \text { yrs. Initial terms: } 2,4, \\
6 \text { yrs. } \\
{\left[\mathrm{lbid}^{2}\right]}\end{array}$ & $\begin{array}{l}\$ 810,000 \text { per yr. } \\
\text { [16 id.] }\end{array}$ & $\begin{array}{l}\text { By President at his pleasure [Cf. } \\
\text { Meyers v. U. S., 272 U. S. } 52 \\
(1926) ; \text { Rathbun v. U. S., } 295 \\
\text { U. S. } 602 \text { (1935)] }\end{array}$ \\
\hline $\begin{array}{l}\text { By Governor (Chairman desig- } \\
\text { nated by Governor) } \\
{[89 \text { (a)] }}\end{array}$ & $\begin{array}{l}6 \text { yrs. Initial terms: } 2,4 \text {, } \\
6 \text { yrs. } \\
{[89 \text { (a)] }}\end{array}$ & $\begin{array}{l}\text { Chairman, } \$ 3,600 \text { per yr. } \\
\text { Assoc. Members, } \$ 10 \text { per } \\
\text { day }[\$ 9(\mathrm{~b})]\end{array}$ & $\begin{array}{l}\text { By Governor "at his pleasure" } \\
\text { [CoDE \& 776] }\end{array}$ \\
\hline $\begin{array}{l}\text { By Governor } \\
{[810(\mathrm{e})]}\end{array}$ & Not specified & $\begin{array}{l}\text { Traveling expenses } \\
{[\$ 10(c)]}\end{array}$ & See above \\
\hline $\begin{array}{l}\text { By Governor } \\
\text { [5 } 10(\mathrm{e})]\end{array}$ & Not specified & $\begin{array}{l}\text { Traveling expenses } \\
{[\S 10(e)]}\end{array}$ & See above \\
\hline $\begin{array}{l}\text { By Governor }[\$ 75] \text { (Chairman } \\
\text { clected by Comm'n) } \\
{[876]}\end{array}$ & $\begin{array}{l}4 \text { yrs. [8 77] Initial terms: } \\
2 \text { Comm'rs, } 1 \text { yr; others, } \\
2,3,4 \text { yrs. [88 } 84-87]\end{array}$ & $\begin{array}{l}\$ 10 \text { per day (not more } \\
\text { than \$1200 per yr.) } \\
\text { Traveling expenses [\$ 76] }\end{array}$ & $\begin{array}{l}\text { By Governor at his pleasure } \\
\text { [PoLIT. CODE \& 349] }\end{array}$ \\
\hline $\begin{array}{l}\text { By Comm'rs of District (Chair- } \\
\text { man, Comm'rs of District, also } \\
\text { Chairman of Board) } \\
{[816 \text { (a)] }}\end{array}$ & $\begin{array}{l}3 \text { yrs. Initial term of em- } \\
\text { ployee representative, } 2 \\
\text { yrs. I\$ } 16 \text { (a)] }\end{array}$ & $\begin{array}{l}\text { Comm'rs of Dist. receive } \\
\text { no extra compensation; } \\
\text { other two members, \$10 } \\
\text { per day } 1 \$ 16(\mathrm{c})] \\
\end{array}$ & $\begin{array}{l}\text { Comm'rs of Dist.. hy President } \\
\text { [see cases, supra]; other members, } \\
\text { by Comm'rs } \\
\text { [CoDE, tit. 20, } 828] \\
\end{array}$ \\
\hline $\begin{array}{l}\text { By Governor, with advice and } \\
\text { consent of Council (Representz- } \\
\text { tive of public, chairman) } \\
{\left[\frac{\text { If }}{9} \text { I (a)] }\right.}\end{array}$ & $\begin{array}{l}6 \text { yrs. Initial terms: } 2,4 \text {, } \\
6 \mathrm{yrs} . \\
189 \mathrm{I}(\mathrm{a})]\end{array}$ & $\begin{array}{l}\$ 6,000 \text { per yr. Chairman, } \\
\$ 6,500 \text { per yr. } \\
{[\$ 9 \text { I (b)] }}\end{array}$ & $\begin{array}{l}\text { By Governor for cause, with } \\
\text { advice and consent of Council. } \\
\text { [LAws ANA. c. 30, } 8 \text { 9] }\end{array}$ \\
\hline $\begin{array}{l}\text { By Governor, with advice and } \\
\text { consent of Council } \\
189 \mathrm{~N}(\mathrm{a})]\end{array}$ & $\begin{array}{l}6 \text { yrs. Initial terms: } 2,4, \\
6 \text { yrs. } \\
{[89 \mathrm{~N}(\mathrm{a})]} \\
\end{array}$ & $\begin{array}{l}\text { Actual traveling and in- } \\
\text { cidental expenses } \\
\text { [8 } 9 \mathrm{~N} \text { (a)] }\end{array}$ & See above \\
\hline $\begin{array}{l}\text { By Governor, with advice and } \\
\text { consent of Couneil } \\
\text { [PUB. LAws C. 174. \& 1] }\end{array}$ & $\begin{array}{l}3 \text { yrs. } \\
{[\text { Id. } \$ 2]}\end{array}$ & $\begin{array}{l}\$ 3000 \text { per yr. and ex- } \\
\text { penses } \\
{[I d . \$ 4]}\end{array}$ & $\begin{array}{l}\text { For cause by Governor, with ad- } \\
\text { vice and consent of Council } \\
{[I d .8 \text { 2] }}\end{array}$ \\
\hline $\begin{array}{l}\text { By Governor, with advice and } \\
\text { consent of Senzte } \\
\text { [lbid.] }\end{array}$ & $\begin{array}{l}\text { Terminates with term of } \\
\text { appointing Governor } \\
\text { [Ibid.] }\end{array}$ & $\begin{array}{l}\$ 12,000 \text { per } y r . \text { and } \\
\text { expenses } \\
{[I d . \$ 17]}\end{array}$ & $\begin{array}{l}\text { By Governor when in public in- } \\
\text { terest } \\
{[1 d . \$ 16 ; c .56 \mathrm{a}, 811]}\end{array}$ \\
\hline $\begin{array}{l}\text { By Governor } \\
{[8518(4)]}\end{array}$ & $\begin{array}{l}6 \text { yrs. Initial terms: } 2,4, \\
6 \mathrm{yrs} \\
18518 \text { (4)I } \\
\end{array}$ & $\begin{array}{l}\text { Actual traveling and in- } \\
\text { cidental expenses } \\
{[\$ 578(4)]}\end{array}$ & $\begin{array}{l}\text { By Governor for ineficiency, neg- } \\
\text { leet of duty, malfeasance, etc. } \\
{[\$ 578 \text { (4)] }}\end{array}$ \\
\hline $\begin{array}{l}\text { By Governor [Id. } 49-1802] \text { (Chair- } \\
\text { man elected by Comm'a for } 2 \\
\text { yrs. } \\
\text { [Id. 49-1804] }\end{array}$ & $\begin{array}{l}4 \text { yrs. } \\
\text { [Id. 49-1802] }\end{array}$ & $\begin{array}{l}\text { Present salary of } \$ 3,600 \\
\text { per yr. [Id. } 49-1803 \text { ] To } \\
\text { continue without addi- } \\
\text { tional compensation [ } 18]\end{array}$ & $\begin{array}{l}\text { By Governor for inefficiency, neg- } \\
\text { lect of duty, or malfeasance in } \\
\text { office } \\
\text { [CODE, 49-1803] }\end{array}$ \\
\hline $\begin{array}{l}\text { By Governor, with consent of } \\
\text { Senate [Id. 42-1-1] Chairman } \\
\text { elected by Comm'n [Id. 42-1-6] }\end{array}$ & $\begin{array}{l}6 \text { yrs. } \\
\text { [Id. 42-1-1] }\end{array}$ & $\begin{array}{l}\$ 4,000 \text { per yr. } \\
{[I d .42-1-5]}\end{array}$ & $\begin{array}{l}\text { By Governor for inefficiency, neg- } \\
\text { lect of duty, malfeasance, etc. } \\
\text { [Id. } 42-1-3]\end{array}$ \\
\hline $\begin{array}{l}\text { As Industrial Commission prescribes } \\
{[827 \text { (b)] }}\end{array}$ & & $\begin{array}{l}\text { None } \\
{[827 \text { (b)] }}\end{array}$ & \\
\hline $\begin{array}{l}\text { By Governor }[\$ 10 \text { (1)] (Chairman } \\
\text { elected by Comm'n) } \\
\text { [\$ } 10(3)]\end{array}$ & $\begin{array}{l}6 \text { yrs. Initial terms: } 2,4 \text {, } \\
6 \text { yrs. } \\
\text { [8 } 10 \text { (1)] }\end{array}$ & $\begin{array}{l}\$ 4,000 \text { per yr. } \\
{[\$ 10(2)]}\end{array}$ & $\begin{array}{l}\text { By Governor, after, public hear- } \\
\text { ing, for gross inefficiency, neglect } \\
\text { of duty, malfeasance, etc. } \\
\text { [§ } 10 \text { (1)] }\end{array}$ \\
\hline $\begin{array}{l}\text { By Unemployment Compensation } \\
\text { Commicsion }[811(5)]\end{array}$ & Not specified & $\begin{array}{l}\text { Necessary expenses } \\
|\S 11(5)|\end{array}$ & \\
\hline $\begin{array}{l}\text { By Unemployment Compensation } \\
\text { Commission }[8 \text { 11 (5)] }\end{array}$ & Not specified & $\begin{array}{l}\text { Necessary expenses } \\
{[\S 11(5)]}\end{array}$ & \\
\hline $\begin{array}{l}\text { By Governor, with advice and } \\
\text { consent of Senate [8 101.02] }\end{array}$ & 6yrs. & & $\begin{array}{l}\text { By Governor for cause } \\
{\left[\begin{array}{l}\text { [8 } 17.07(3)]\end{array}\right.}\end{array}$ \\
\hline $\begin{array}{l}\text { By Industrial Commission } \\
{[8 \text { 103.14 (5)] }}\end{array}$ & Not specified & $\begin{array}{l}\text { Necessary cxpenses } \\
{[\delta \text { 108.14 (5)] }}\end{array}$ & \\
\hline
\end{tabular}


effective when filed with the secretary of state, and in one of these two $0^{8}$ the approval of the governor and council is prerequisite to filing.

2. Commission Reports. The commissions are required to submit an annual or a biennial report and recommendations to the governor, ${ }^{9}$ or to the legislature, ${ }^{10}$ or to both, ${ }^{11}$ or simply to compile and publish such report. ${ }^{12}$ Provision is also made for the publication of the reports, rules, and other matters of which the employers, employees, and public should be informed. ${ }^{13}$ The commissions are generally authorized to coöperate with the Social Security Board, to make all reports required by the Board, and to comply with its regulations. ${ }^{14}$

3. Employers Records and Reports. Employers are required to keep records of employment and other related matters. Such reports are to be open to inspection by the commission which may require that they be filed. ${ }^{15}$

4. Staff Personnel. In four states $^{16}$ appointments are to be made under civil service regulations. In two jurisdictions, ${ }^{17}$ no limitations are imposed on the exercise of the power to appoint subordinates. In the other states appointments are to be on a "merit basis,"18 or "nonpartisan basis" subject to approval of the governor, ${ }^{10}$ or on a "nonpartisan merit basis" ${ }^{20}$ subject to approval of the governor. ${ }^{21}$ Some acts provide for the appointment of an executive officer who shall serve as secretary to the commission. ${ }^{21^{2}}$ Where the industrial commissioner or commission is authorized to administer the act, ${ }^{22}$ an unemployment compensation division has been created under the general appointing power.

5. Funds. To facilitate compliance with Section 303 (a) (4)-(5) of the Federal Social Security Act, the acts generally provide for two separate funds: one usually called the Unemployment Compensation Fund ${ }^{23}$ to be used only for payment of

${ }^{8}$ Mass. 9 J.

Ala. $\$$ ro (a) (annual); Cal. $\$ \$ 33$ (quarterly financial report to governor), 75 , PoL. CodE (r931) $\$ 354$ (biennial); N. H. $\$ 40$ (annual); Ore. $\$ 20$ (b) (annual); Utah, Rev. StAT. (1933) 42-1-95 (biennial); Wash. §rI (I) (annual).

${ }^{20}$ Dist. of Col. $\$ \S \mathrm{r}_{4}$ (c)-(d) (annual report to Congress); N. Y. Consol. LAws (I930) c. $32, \$ 35$ (annual).

${ }^{12}$ Mass. $\$ 9 \mathrm{~J}$ (annual). $\quad{ }^{20} \mathrm{Wis.} \$ 108.14(6)$.

${ }^{23} \mathrm{Ala}$. $\$ 10$ (c); Cal. $\$ \$ 90$ (b)-(d), gI (c); Dist. of Col. $\$ I_{4}$ (b) (publication of rules prior to effective date), $\$ 17$ (publication of reciprocal agreements); Mass. $\$ 40 ;$ N. H. $\$ 42$; Ore. $\$ 20$ (a)-(b); Utah, Rev. STAT. (I933) 42-I-95; Wash. \$II (3); Wis. \$§I08.14 (2), 108.15 (10)-(12).

${ }^{14}$ Ala. \$ro (i); Cal. \$97; Dist. of Col. §I4 (c); Mass. \$\$42, 43 (b); N. H. \$47; N. Y. \$524; Ore. $\$ \$ 19$ (d), 2I (c); Utah $\$ 39$ (Governor to make reasonable rules to comply with Federal law); Wash. §II (9); Wis. $\$$ I08.20 (I).

${ }^{15}$ Ala. §ro (g); Cal. \$9o (c) (Commission "shall keep ... records of employment"); Dist. of Col. $\$ 18$ (b) Mass. $\$ 43$ (a); N. H. \$45; N. Y. \$521; Ore. \$21 (a); Utah, \$31; Wash. \$1I (7); Wis. \$ro8.14 (2).

${ }^{10}$ Cal. $\$ 88$ (Executive offeer not subject to civil service); Mass. $\$ 9$ K; N. X. $\$ 518$ (I); Wis. Stat. (1933) §r 4.7 I (r).

${ }^{18}$ Ore. $\$ 19(\mathrm{~b})$.

${ }^{\infty}$ Wash. \$II (4).

${ }^{17}$ Dist. of Col. $\$ 14$ (a); Utah, $\$ 27$ (a).

${ }^{10}$ N. H. $\$ 43$ (and council).

212 Calif. \$88; Dist. of Col. \$16 (b); cf. Mass. $\$ 9$ I (d).

${ }^{2}$ N. H. $\$ 40 ;$ N. Y. 518 (I); Utah, $\$ 27$ (a) (no appointments because the act is not in effect); Wis. $\$ 108.14$ (I).

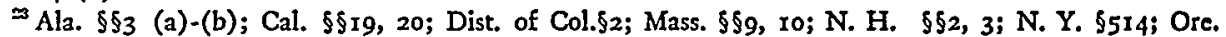
§4; Utah \$22; Wash. \$\$4 (I)-(2); Wis. \$108.16 (I). 
benefits; the other usually called the Unemployment Administration Fund ${ }^{24}$ to be used only for administrative expenses. Appropriations from the state for administration and any similar grants by the federal government under Title III are placed in the second fund; contributions collected and interest earned thereon are to be credited to the first, which, in conformity to the Federal Act, is directed to be deposited in the Unemployment Trust Fund in the United States Treasury. ${ }^{25}$ In Utah appropriations are provided but no administrative fund created. ${ }^{26}$

6. Employment Stabilization. The commission is generally authorized to investigate and to take other action with a view to stabilizing employment. ${ }^{27}$ The New York provision ${ }^{28}$ is representative:

"It shall be one of the purposes of this article to promote the regularization of employment in enterprises, localities, industries, and the state. The commissioner shall take such steps as are within his means for the reduction and prevention of unemployment. To this end the commissioner may employ experts, and may carry on and publish the results of any investigations and research which he deems relevant, whether or not directly related to the other purposes and specific provisions of this article."

7. Reciprocal Agreements. Some of the commissions ${ }^{29}$ are given the power to make reciprocal agreements with the proper agency in other states having unemployment compensation laws so that migratory employees will not lose their right to benefits by leaving the state of original employment.

^Ala. $\$ 16$ (a); Cal. \$23; Dist. of Col. \$15; Mass. \$45; N. H. \$\$57, 58; N. Y. \$520; Ore. \$22; Wash. $\S 17(1)$; Wis. $§ 108.20$. Provision is generally made for a special "employment service account" within each fund.

${ }^{25}$ Ala. \$3 (d); Cal. \$22; Dist. of Col. \$7; Mass. \$12; N. H. \$4; N. Y. \$515 (3); Ore. \$23 (b); Wash. $\$ 4$ (4); Wis. \$108.16 (10); cf. Utah, \$39.

Utah, $\S_{4}$ I (A provision contained therein that the amount of the appropriation is to be repaid from the Unemployment Reserve Fund within three years may prevent this state from securing the approval of the Social Security Board. See Social Security Act, $\$ 903$ (a) (4).

${ }^{\top}$ Ala. §ro (f); Cal. §9r; N. H. §44; N. Y. \$5I8 (3); Utah, \$27 (e); Wash. §Ir (6); Wis. §ro8.r4 (6).

${ }^{23}$ N. Y. $\$ 518(3)$.

${ }^{20}$ Ala. $\$ 12 ;$ Dist. of Col. $\S I_{7} ;$ N. H. $\$ 48 ;$ Wash. $\$ 13$. It is provided in the state acts that such agreements are subject to the approval of the governor. A question arises whether they may not be regarded as constituting interstate compacts requiring the approval of the United States Congress. See U. S. ConsT., Art. I, 5ro, cl. 3 . 